\title{
Morphological and genetic variations in "Balady" Mandarin induced by gamma irradiation
}

\author{
A.N. El-Banna ${ }^{1}$, A. R. El-Shereif ${ }^{2}$ and Doaa M. Abou Elyazid ${ }^{2}$ \\ ${ }^{1}$ Genetics Department, ${ }^{2}$ Horticulture Department, Faculty of Agriculture, Kafrelsheikh University, Egypt \\ Corresponding author: antarsalem@yahoo.com
}

\begin{abstract}
Induced mutagenesis using gamma ray has been proven applicable to improve varieties of many genotypes of crop species. The present investigation was carried out to study genetic variability induced by gamma rays in Balady mandarin. Bud woods were irradiated with doses of 0,2, 4, 6 and $8 \mathrm{kr}$ along with control and budded onto volkamer lemon rootstock. Bud survival percentage decreased with increasing dose of gamma radiation. Doses of 6 and $8 \mathrm{Kr}$ were lethal where the $\mathrm{LD}_{50}$ was achieved at $2.1 \mathrm{Kr}$. Shoot length, leaf number per plant, leaf area per plant and stomata width decreased significantly by increasing the gamma dose from 0 to $4 \mathrm{Kr}$. Whereas, stomata number per unit area increased significantly compared to control. Molecular analysis of some induced mutants using ISSR and RAPD markers revealed that, the polymorphism percentage ranged from $50 \%$ to $80 \%$ when the ISSR primers were used and from $73.33 \%$ to $100 \%$ for RAPD primers. The $4 \mathrm{Kr}$ treatment caused the highest polymorphism percentage $(69.05 \%$ and $85.32 \%$ ), whereas the $2 \mathrm{Kr}$ treatment had $62.5 \%$ and $74.23 \%$ for the ISSR and RAPD primers respectively. Gamma irradiation treatments included alteration in protein bands intensity, appearance of new bands and disappearance of other bands. The most visible changes in protein patterns were the appearance of new bands with molecular sizes of 264, 196 and $139 \mathrm{KD}_{\mathrm{a}}$ in some selections of $4 \mathrm{Kr}$ treatment, and bands of $87,86,82,51,45,30$ and $9 \mathrm{KD}_{\mathrm{a}}$ in selections of 2 and $4 \mathrm{Kr}$ treatments. The $4 \mathrm{Kr}$ treatment achieved more genetic variation than the $2 \mathrm{Kr}$ treatment.
\end{abstract}

Keywords: Mandarin, Gamma rays, Genetic variability, Molecular markers, Protein pattern

\section{Introduction}

Citrus is one of the most important fruit crops worldwide and plays a major role in the economic development of some areas. Mandarins are the second most important group of citrus plants in the world, with climatic adaptation among the cultivated citrus. Genetic improvements in citrus by conventional plant breeding methods have been limited because of their complex reproductive biology; such as high heterozygosity, apomixis, polyembryony, cross- and self- incompatibility, quantitative and qualitative traits in nature while long juvenility are expensive, timeconsuming and limited rate of improvement (Gulsen et al. 2010; Xiao et al. 2009). The improvement of citrus has been largely made through selection of naturally occurring somatic mutants or chance seedlings (Cameron and Frost, 1968; Xiao et al. 2009). Induced mutagenesis of crops has been successfully utilized to increase frequencies of somatic variants and several important commercial citrus varieties have arisen as bud mutation. Mutagenesis offers the possibility of changing only one or a few traits of firstrate cultivars, which can further enhance quality and quantity of crops (Xu et al. 2012), while preserving the overall traits. Maluszynski et al. (1995) stated that induced mutations (in vivo and in vitro) have been employed primarily to improve particular traits in well-adapted local varieties or to generate variations difficult to find in germplasm collections. Mutation induction techniques using gamma ray is a good tool for increasing variability and has been proven applicable to improve characteristics of many citrus genotypes such as seedlessness (Chen et al. 1991; Froneman et al. 1996; Hearn 1986; Micke et al. 1985;
Spiegel-Roy et al. 1990, 1985; Sutarto et al. 2009), spinelessness (Kukimura et al. 1976) and for inducing changes in fruit and juice colour (Sutarto et al. 2009; Wu et al. 1986).

Mutation induction has a high potential of bringing genetic changes and crops improvement and it has contributed considerably to plant breeding. Gamma irradiation is the most common physical mutagen used in inducing mutation in fruit breeding (Perdieri, 2001). Many investigators used gamma irradiation in improving citrus species (Spiegl and Padova, 1973; Hearn, 1984; Espino, 1986; Cheng et al. 1997; Gulsen et al. 2007 and Majd et al. 2009). Rapid development in molecular biotechnology has also partially solved some of the limitations associated with conventional citrus breeding (Xiao et al. 2009). Early genetic detection of variants for crop improvement confirms the success of breeding programmes such as that reported for Ochreinauclea missionis (Chandrika and Rai 2009), Greek fir (Krajnáková et al. 2011) and Cymbopogon pendulus (Bhattacharya et al. 2010). In Citrus, a wide variety of DNA based markers has been used in order to study their genetic variation as well as phylogenetic and taxonomic relationship among different genera, and some of the important examples are: RAPD ( Federici et al. 1998; Nicolosi et al. 2000) and ISSR (Gulsen and Rosse 2001a; Fang et al. 1998). ISSR markers have successfully been used in Citrus to identify closely related varieties, to determine genetic diversity, assess phylogenetic relationships among the Citrus and related genera (Gulsen and Roose 2001b; Marak and Laskar 2010; Shahsavar et al. 2007; Uzun et al 2009a). ISSR has been previously used to fingerprint trifoliate orange germplasm accessions and other closely related Citrus cultivars (Fang and Roose, 
1997). Furthermore, RAPD markers (William et al. 1990) provide a fast and easy approach for taxonomic classification and cultivar-typing of fruit trees. This type of DNA markers has the advantage of being readily employed, requiring very small amounts of genomic DNA, and eliminating the need for blotting and radio-active detection (Cipriani et al., 1996). In citrus, RAPD markers have been used for genetic diversity analysis (Shaaban et al., 2006; Shahsavar et al., 2007; Hvarleva et al., 2008), chimeras (Sugawara et al., 2002) and phylogenetic analysis (Nicolosi et al., 2000). One of the biochemical methods extensively used in taxonomic and assessment of genetic diversity studies is the electrophoretic analysis of the proteins using Sodium Dodecylsulphate Polyacrylamide Gel Electrophoresis (SDS-PAGE). These proteins are physiologically stable and easy to handle (Ladizinsky and Hymowitz, 1979).

This study aimed to increase the genetic variability by using gamma rays as a physical mutagen, identifying the appropriate dose that gives the highest genetic variations with suitable survival rate and early detection of the induced genetic variations via biochemical and molecular markers.

\section{Materials and Methods}

\section{Plant materials and gamma ray treatments}

Fresh, non-dormant bud woods of Balady mandarin (Citrus reticulata Blanco) were exposed to gamma rays at doses of $0,2,4,6$ and $8 \mathrm{Kr}$ and were budded onto volkamer lemon rootstock. Plants originated from irradiated bud woods along with plants from untreated bud woods were grown in the green house for further observation. Bud survival percentage and growth parameters such as shoot length, leaf number/plant, area/leaf and total leaf area/plant. Leaf area were recorded 4 months after budding was measured using portable area meter model LI-3000A (LI-COR). Stomata number, length and width were carried out as follows; the lower epidermis of the leaves was covered with a thin layer of clear nail polish and left to dry for few minutes to conform to the shape of the surface of the leaf, then it was peeled off, placed on a microscope slide and a drop of safranine was added then, a cover slip was placed over the peel. The slides were examined under a light microscope (Leica DM 1000) equipped with a digital camera. Photos were taken under magnifying power of $400 \mathrm{X}$ and the photos were further processed for obtaining stomata number, length and diameter using Leica Image Manger software.

\section{DNA isolation, ISSR and RAPD markers}

Total DNA was extracted from young leaves using the cetyl trimethylammonium bromide (CTAB) method (Doyle and Doyle 1990). Approximately 100$150 \mathrm{mg}$ of leafs were ground using $600 \mu \mathrm{L}$ of preheated $\left(65^{\circ} \mathrm{C}\right)$ extraction buffer $(2 \% C T A B, 20 \mathrm{mM}$ EDTA, $100 \mathrm{mM}$ Tris-HCl, $1.4 \mathrm{M} \mathrm{NaCl}, 2 \%$ polyvinylpyrrolidone $(P V P), 0.2 \%$ mercaptoethanol) then transferred to a centrifuge tube $(2 \mathrm{~mL})$ and incubated for $30 \mathrm{~min}$ in a $65^{\circ} \mathrm{C}$ water bath, the samples were inverted every $5 \mathrm{~min}$. $600 \mu \mathrm{L}$ of chloroformisoamyl alcohol (24:1) was added and mixed by inverting the tubes carefully for 10 times and the cells were centrifuged at $12000 \mathrm{rpm}$ for $10 \mathrm{~min}$ at room temperature. The supernatant was collected and carefully mixed with two third volume of ice cold Isopropanol and the DNA samples were collected by centrifuging for $10 \mathrm{~min}$. RNaseA $(10 \mu \mathrm{g} / \mathrm{ml})$ was added to the $50 \mu \mathrm{l}$ of TE buffer (10 mM Tris and 0.1 $\mathrm{mM}$ EDTA) prior to dissolving the DNA to remove any RNA in the preparation and the mixure was incubated at $37 \mathrm{C}$ for $30 \mathrm{~min}$. $100 \mu \mathrm{l}$ and $750 \mu \mathrm{l}$ volumes of $3 \mathrm{M}$ sodium acetate and ice-cold absolute ethanol were added respectively. The DNA was collected by high-speed centrifugation for $10 \mathrm{~min}$, and then carefully washed with ice-cold absolute and $70 \%$ ethanol and centrifuged at $120000 \mathrm{rpm}$ for $10 \mathrm{~min}$. Finally, the samples were dried at room temperature and dissolved in 50-100 $\mu \mathrm{l}$ of TE buffer The quality and concentration of DNA were determined by EMPLEN photometer P330. For DNA amplification, seven ISSR primers (Table 1) and 9 decamer RAPD (Table 2) primers (Operon, Germany) were used. PCR was performed as follows: $94^{\circ} \mathrm{C}$ for $5 \mathrm{~min}$; followed by 35 cycles of $94^{\circ} \mathrm{C}$ for $1 \mathrm{~min}$, specific annealing temperature (Ta) according the primer sequence for $30 \mathrm{sec}$ and $72^{\circ} \mathrm{C}$ for $3 \mathrm{~min}$ and the final extension step at $72^{\circ} \mathrm{C}$ for $10 \mathrm{~min}$. Amplification was carried out in MJ Mini BioRAD, thermal cycler in $25 \mu$ r reaction volume containing the following reagents: $1.0 \mu \mathrm{l}$ of dNTPs $(10 \mathrm{mM}), 1.0 \mu \mathrm{l}$ of $\mathrm{MgCl}_{2}(25 \mathrm{mM}), 5 \mu \mathrm{l}$ of $10 \mathrm{x}$ buffer, $1.0 \mathrm{ul}$ of primer (10 pmol), $1.0 \mu \mathrm{l}$ of DNA $(25 \mathrm{ng} / \mu \mathrm{l}), 0.3 \mu \mathrm{l}$ of taq polymerase $(5 \mathrm{u} / \mu \mathrm{l})$ and 15.7 d.d. $\mathrm{H}_{2} \mathrm{O}$. The ISSR and RAPD products were electrophoresed in $1.5 \%$ agarose gel in TAE buffer (40 mM Tris-acetate, $20 \mathrm{mM}$ glacial acetic acid, $1 \mathrm{mM}$ EDTA, $\mathrm{pH} 7$ ) at $75 \mathrm{~V}$. The gel was stained with ethidium bromide and then distained with tap water and bands were detected on UV-trans-illuminator, photographed by Gel documentation system UVITEC, UK). and according to analysis by Phoretix program 1D gel analysis software version 4.01

Table 1. List of ISSR primers screened.

\begin{tabular}{ccc}
\hline No. & Primer name & Sequence $5^{-} \rightarrow 3^{-}$ \\
\hline 1 & UBC 848 & $(\mathrm{CA})_{8} \mathrm{RG}$ \\
\hline 2 & HB 12 & $(\mathrm{CAG})_{3} \mathrm{GC}$ \\
\hline 3 & $844 \mathrm{~A}$ & $(\mathrm{CT})_{8} \mathrm{AC}$ \\
\hline 4 & $17889 \mathrm{~A}$ & $(\mathrm{CA})_{6} \mathrm{AC}$ \\
\hline 5 & UBC 836 & $(\mathrm{AG})_{8} \mathrm{YA}$ \\
\hline 6 & UBC 842 & $(\mathrm{GA})_{8} \mathrm{YG}$ \\
\hline 7 & HB 15 & $(\mathrm{GTG})_{3} \mathrm{GC}$ \\
\hline $\mathrm{Y}=\mathrm{C}, \mathrm{T}$ & $\mathrm{R}=\mathrm{A}, \mathrm{G}$ &
\end{tabular}

$\mathrm{Y}=\mathrm{C}, \mathrm{T} \quad \mathrm{R}=\mathrm{A}, \mathrm{G}$ 
Table 2. List of RAPD primers used.

\begin{tabular}{|c|c|}
\hline Primers & Sequences \\
\hline OPA-01 & 5' - CAGGCCCTTC -3' \\
\hline OPA-02 & $5^{\prime}-$ TGCCGAGCTG -3' \\
\hline OPA-03 & 5'- AGTCAGCCAC -3' \\
\hline OPA-04 & 5'- AATCGGGCTG -3' \\
\hline OPA-05 & 5'- AGGGGTCTTG -3' \\
\hline OPA-06 & 5'- GGTCCCTGAC -3' \\
\hline OPA-07 & 5'- GAAACGGGTG -3' \\
\hline OPC-14 & $5^{\prime}$ - TGCGTGCTTG -3' \\
\hline OPV-07 & $5^{\prime}$ - GAAGCCAGCC -3' \\
\hline
\end{tabular}

\section{Protein electrophoresis}

Protein extracts were prepared from young leaves ( $0.5 \mathrm{~g}$ of mandarin plants) and homogenates were obtained by mechanically grinding in $500 \mu \mathrm{l}$ of the protein extraction buffer $(62.5 \mathrm{mM}$ Tris-Hcl, $\mathrm{pH} 6.8$, $2 \%$ SDS, $10 \%$ glycerol, $5 \% \beta$-mercaptoethanol, $5 \mathrm{M}$ Urea and $0.01 \%$ bromo-phenol blue) was added and mixed well by vortexing. Protein extracts were centrifuged at $14,000 \mathrm{rpm}$ for $10 \mathrm{~min}$ at $4{ }^{\circ} \mathrm{C}$ and apply in $12 \%$ (SDS-PAGE) according to (Laemmli, 1970), Molecular weights of different bands were calibrated with a mixture of standard protein markers (Molecular Weight Marker, M. W. 14.000- 66.000; Catalog No. SDS7). The banding profile was stained by Coomase blue dye then photographed and scored.

\section{Statistical analysis}

The obtained data were statistically analyzed by subjecting to analysis of variance (ANOVA) according to Snedecor and Cochran (1980) using MSTAT program and LSD used to compare among means of treatments according to Duncan (1955) at probability of $5 \%$.

\section{RESULTS}

\section{Bud survival percentage and $L_{50}$}

Bud survival percentage (sprouted buds after budding) was reduced in response to exposure to gamma rays as shown in Figure (1). Doses of 6 and 8 $\mathrm{Kr}$ were lethal to Balady mandarin buds, where all treated buds by these two doses were killed. Based on the bud survival percentage, the $\mathrm{LD}_{50}$ was achieved at $2.1 \mathrm{Kr}$.

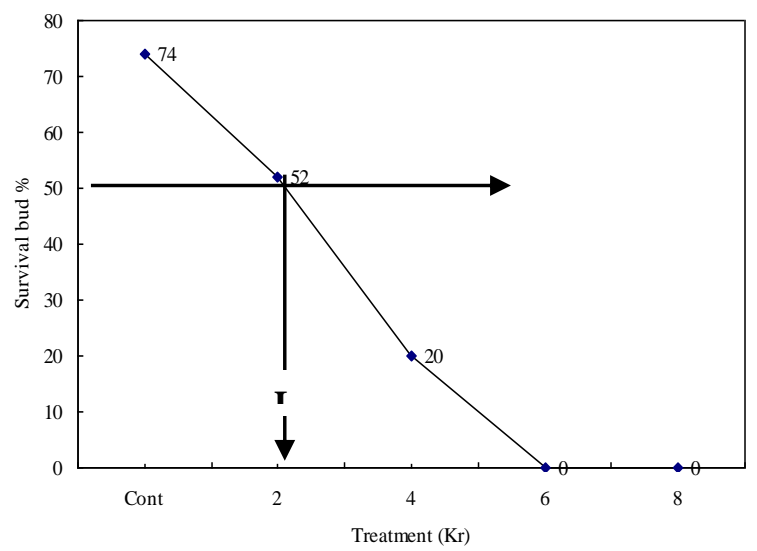

Fig. 1. Effect of gamma irradiation doses $(0,2,4,6,8$ $\mathrm{Kr}$ ) on bud survival percentage and $\mathrm{LD}_{50}$

\section{Effect of gamma rays on some morphological characters}

Data presented in Table (3) showed that shoot length, leaf number / plant and area / leaf were decreased significantly by increasing the gamma dose from 0 to $4 \mathrm{Kr}$.

Table 3. Effect of bud radiation on some vegetative parameters of Balady mandarin plants.

\begin{tabular}{lcccc}
\hline Treatment & Shoot length $(\mathrm{cm})^{*}$ & Leaf No/plant* & Area/leaf $\left(\mathrm{cm}^{2}\right)$ & Total leaf area $\left(\mathrm{cm}^{2}\right)$ \\
\hline Control & $41.60 \mathrm{a}$ & $30.40 \mathrm{a}$ & $18.84 \mathrm{a}$ & $572.74 \mathrm{a}$ \\
\hline $2 \mathrm{Kr}$ & $28.08 \mathrm{~b}$ & $23.67 \mathrm{~b}$ & $16.96 \mathrm{~b}$ & $401.44 \mathrm{~b}$ \\
\hline $4 \mathrm{Kr}$ & $24.50 \mathrm{c}$ & $22.00 \mathrm{~b}$ & $15.44 \mathrm{c}$ & $339.68 \mathrm{c}$
\end{tabular}

Means followed by the same letters are not significant at 0.05 level according to Duncan's test.

*Shoot length and leaf number were recorded four months after budding

The results in Table (4) showed that stomata number / unit area $\left(1 \mathrm{~mm}^{2}\right)$ was increased significantly as a result of exposing to gamma rays compared to control, the highest number was recorded at $2 \mathrm{Kr}$ followed by $4 \mathrm{Kr}$ with no significant difference while control recorded the lowest value. There was no significant effect for irradiation on stomata length, whereas stomata width was decreased by exposing to gamma rays recording its lowest value at $2 \mathrm{Kr}$ and the differences were significant among treatments (Table 4).

Table 4. Effect of bud radiation on stomata density and dimension of Balady mandarin leaves.

\begin{tabular}{lccc}
\hline Treatment & Stomata No.* & Stomata length $(\mu \mathrm{m})$ & Stomata width $(\mu \mathrm{m})$ \\
\hline Control & $14.06 \mathrm{~b}$ & $105.36 \mathrm{a}$ & $87.35 \mathrm{a}$ \\
\hline $2 \mathrm{Kr}$ & $22.82 \mathrm{a}$ & $104.06 \mathrm{a}$ & $81.1 \mathrm{c}$ \\
\hline $4 \mathrm{Kr}$ & $20.60 \mathrm{a}$ & $105.64 \mathrm{a}$ & $82.41 \mathrm{~b}$ \\
\hline
\end{tabular}

Means followed by the same letters are not significant at 0.05 level according to Duncan's test.

* Stomata No was counted in $1 \mathrm{~mm}^{2}$ 


\section{ISSR-PCR analysis}

From the seven screened ISSR primers in the studied treatment selections, only five were selected as the most informative primers. These primers are UBC848, HB12, 844A, 17889A and UBC836. Results in Tables (5 and 6) showed that the five primers revealed polymorphism among treatments selections, a total of 44 amplified bands were obtained, out of which 31 were polymorphic (Table 6). The total number of amplified DNA bands varied between 10 (UBC848, HB12, 844A and 17889A) and four (UBC836).

Table 5. Amplified fragments obtained from the DNAs of Balady mandarin plants resulted from irradiated buds via ISSR-PCR.

\begin{tabular}{|c|c|c|c|c|c|c|c|c|c|c|}
\hline \multirow{2}{*}{$\begin{array}{c}\text { Primer } \\
\text { Cod }\end{array}$} & \multirow{2}{*}{$\begin{array}{l}\text { Size } \\
\text { (bp) }\end{array}$} & \multirow[t]{2}{*}{ Control } & \multicolumn{4}{|c|}{$2 \mathrm{Kr}$} & \multicolumn{4}{|c|}{$4 \mathrm{Kr}$} \\
\hline & & & 1 & 2 & 3 & 4 & 1 & 2 & 3 & 4 \\
\hline \multirow[t]{10}{*}{ UBC848 } & 500 & 1 & 1 & 1 & 1 & 1 & 1 & 1 & 1 & 1 \\
\hline & 468 & 1 & 1 & 1 & 1 & 1 & 1 & 1 & 1 & 1 \\
\hline & 400 & 0 & 1 & 1 & 1 & 1 & 1 & 1 & 1 & 1 \\
\hline & 385 & 0 & 0 & 0 & 0 & 1 & 1 & 1 & 1 & 1 \\
\hline & 371 & 1 & 1 & 1 & 1 & 1 & 0 & 0 & 0 & 1 \\
\hline & 300 & 1 & 1 & 1 & 1 & 1 & 1 & 1 & 1 & 1 \\
\hline & 231 & 1 & 1 & 1 & 1 & 1 & 1 & 1 & 1 & 1 \\
\hline & 200 & 0 & 0 & 0 & 0 & 0 & 1 & 1 & 1 & 0 \\
\hline & 170 & 0 & 0 & 0 & 1 & 0 & 0 & 0 & 1 & 0 \\
\hline & 138 & 1 & 1 & 1 & 0 & 1 & 1 & 1 & 1 & 0 \\
\hline \multirow[t]{10}{*}{ HB12 } & 700 & 1 & 0 & 0 & 0 & 0 & 0 & 0 & 0 & 0 \\
\hline & 469 & 0 & 1 & 1 & 1 & 1 & 0 & 1 & 1 & 0 \\
\hline & 400 & 1 & 1 & 1 & 1 & 1 & 1 & 1 & 1 & 1 \\
\hline & 355 & 1 & 1 & 1 & 1 & 1 & 1 & 1 & 1 & 1 \\
\hline & 300 & 1 & 0 & 0 & 0 & 0 & 0 & 0 & 0 & 0 \\
\hline & 280 & 1 & 1 & 1 & 1 & 1 & 1 & 1 & 1 & 1 \\
\hline & 226 & 0 & 1 & 1 & 1 & 1 & 1 & 1 & 1 & 1 \\
\hline & 200 & 0 & 0 & 0 & 0 & 1 & 1 & 0 & 1 & 1 \\
\hline & 145 & 1 & 0 & 1 & 0 & 0 & 0 & 0 & 0 & 1 \\
\hline & 100 & 0 & 0 & 1 & 0 & 0 & 0 & 0 & 0 & 0 \\
\hline \multirow[t]{10}{*}{$844 \mathrm{~A}$} & 528 & 0 & 0 & 0 & 0 & 0 & 0 & 0 & 1 & 0 \\
\hline & 500 & 0 & 1 & 1 & 0 & 0 & 0 & 0 & 1 & 1 \\
\hline & 400 & 0 & 0 & 1 & 1 & 1 & 1 & 1 & 0 & 1 \\
\hline & 378 & 0 & 1 & 0 & 0 & 0 & 0 & 0 & 1 & 1 \\
\hline & 300 & 1 & 1 & 1 & 1 & 1 & 1 & 1 & 1 & 1 \\
\hline & 268 & 1 & 1 & 1 & 1 & 1 & 1 & 1 & 1 & 1 \\
\hline & 223 & 0 & 0 & 0 & 0 & 0 & 0 & 1 & 0 & 0 \\
\hline & 200 & 0 & 0 & 0 & 1 & 0 & 0 & 0 & 0 & 0 \\
\hline & 160 & 1 & 1 & 0 & 0 & 0 & 0 & 0 & 0 & 0 \\
\hline & 58 & 1 & 1 & 0 & 0 & 0 & 0 & 0 & 0 & 0 \\
\hline \multirow[t]{10}{*}{ 17889A } & 600 & 1 & 1 & 1 & 1 & 1 & 1 & 1 & 1 & 1 \\
\hline & 431 & 1 & 1 & 1 & 1 & 1 & 1 & 0 & 1 & 0 \\
\hline & 423 & 1 & 0 & 0 & 0 & 0 & 0 & 1 & 1 & 1 \\
\hline & 400 & 0 & 0 & 1 & 1 & 1 & 1 & 1 & 1 & 1 \\
\hline & 326 & 0 & 1 & 1 & 1 & 1 & 0 & 1 & 0 & 1 \\
\hline & 264 & 1 & 1 & 1 & 1 & 1 & 1 & 1 & 1 & 1 \\
\hline & 200 & 0 & 1 & 1 & 1 & 1 & 1 & 0 & 0 & 1 \\
\hline & 187 & 0 & 1 & 0 & 1 & 0 & 0 & 0 & 0 & 0 \\
\hline & 157 & 0 & 1 & 1 & 1 & 0 & 0 & 1 & 0 & 1 \\
\hline & 100 & 1 & 1 & 1 & 1 & 0 & 0 & 0 & 0 & 0 \\
\hline \multirow[t]{4}{*}{ UBC836 } & 800 & 1 & 0 & 0 & 0 & 0 & 0 & 0 & 0 & 0 \\
\hline & 400 & 1 & 1 & 1 & 1 & 1 & 1 & 1 & 1 & 1 \\
\hline & 240 & 0 & 1 & 0 & 1 & 0 & 0 & 0 & 0 & 1 \\
\hline & 200 & 1 & 1 & 1 & 1 & 1 & 1 & 1 & 1 & 1 \\
\hline
\end{tabular}


The maximum number of polyomorphic bands (8) was obtained with $844 \mathrm{~A}$ and $17889 \mathrm{~A}$ primers, and the minimum number (2) was obtained with UBC836 primer. The polymorphism percentage ranged from $50 \%$ (primer UBC836) to $80 \%$ (844A and 17889A primers). Table (5) and Fig. (2) showed that UBC848 primer gave 10 different bands with molecular sizes ranged from 500 to $138 \mathrm{bp}$, four of them were monomorphic with sizes of 500, 468, 300, $231 \mathrm{bp}$.

The other bands were polymorphic. Bands with sizes 400, 385, 200 and 170 bp were not detected in the control and were presented in some selections of the irradiation treatments. Whereas, bands with sizes of 371 and $138 \mathrm{bp}$ were presented in the control treatment and absent from some other irradiation treatment selections.

HB12 primer produced 10 different bands ranging from 700 to $100 \mathrm{bp}$, three of which were monomorphic with sizes of 400,355 and $280 \mathrm{bp}$. The other seven bands were polymorphic with percentage of $70 \%$. However, bands with molecular size of 700, 300 and $100 \mathrm{bp}$ were detected only in the control and $2 \mathrm{Kr}$ treatments as unique bands. The $844 \mathrm{~A}$ primer separated also 10 different bands ranged from 528 to $58 \mathrm{bp}$. Among of them eight were polymorphic bands and only two monomorphic (300 and $268 \mathrm{bp}$ ). The polymorphism percentage of this primer was $80 \%$. The bands with molecular sizes of 528, 223 and 200 bp were present as unique bands in some irradiated selections and absent from the control. The 17889A primer had 10 different amplified bands, ranged from 600 to $100 \mathrm{bp}$. of which eight were polymorphic with $80 \%$ polymorphism percentage, and 2 were monomorphic bands sized 600 and 264 bp.

Primer UBC836 gave the lowest total bands (4) compared to the other primers, 2 of which were polymorphic with $50 \%$ polymorphism percentage and the other 2 bands were monomorphic (400 and 200 bp). The molecular size of 800 bp was detected only in the control treatment and absent from the other treatment selections.
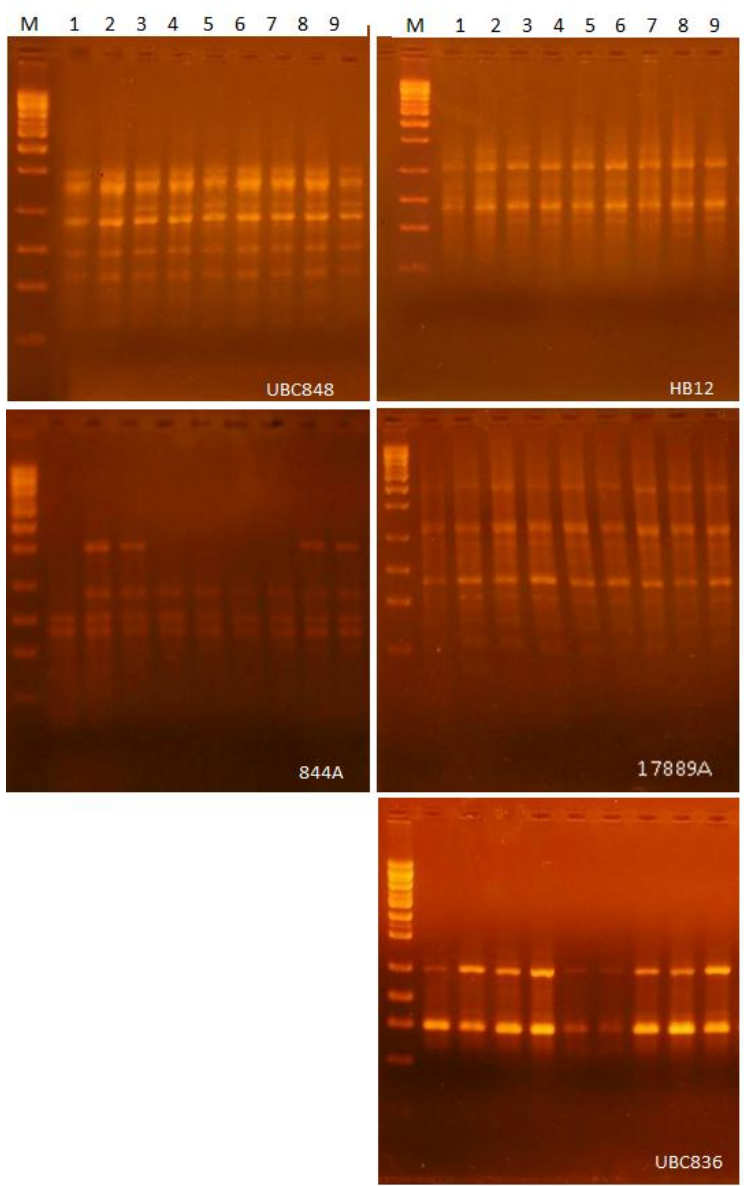

Fig. 2. ISSR fragments amplified from genomic DNA extracted from Balady mandarin shoots resulted from irradiated buds. (M: 100bp DNA ladder, 1: control, 25: $2 \mathrm{Kr}, 6-9: 4 \mathrm{Kr}$ ).

Table 6. Number and types of the amplified DNA bands as well as the total polymorphism percentage generated by five ISSR primers in Balady mandarin buds irradiation.

\begin{tabular}{ccccccc}
\hline $\begin{array}{c}\text { Primer } \\
\text { code }\end{array}$ & $\begin{array}{c}\text { Primer } \\
\text { Sequence } \\
5^{-} \rightarrow 3^{-}\end{array}$ & $\begin{array}{c}\text { No of } \\
\text { monomorphic } \\
\text { bands }\end{array}$ & $\begin{array}{c}\text { No of } \\
\text { polymorphic } \\
\text { bands }\end{array}$ & $\begin{array}{c}\text { Unique } \\
\text { bands }\end{array}$ & $\begin{array}{c}\text { Total } \\
\text { bands }\end{array}$ & $\begin{array}{c}\text { Polymorphism } \\
\%\end{array}$ \\
\hline UBC 848 & $(\mathrm{CA}) 8 \mathrm{RG}$ & 4 & 6 & 0 & 10 & 60 \\
\hline HB 12 & $(\mathrm{CAG}) 3 \mathrm{GC}$ & 3 & 7 & 3 & 10 & 70 \\
\hline $844 \mathrm{~A}$ & $(\mathrm{CT}) 8 \mathrm{AC}$ & 2 & 8 & 3 & 10 & 80 \\
\hline 17889 A & $(\mathrm{CA}) 6 \mathrm{AC}$ & 2 & 8 & 0 & 10 & 80 \\
\hline UBC 836 & $(\mathrm{GA}) 8 \mathrm{YG}$ & 2 & 2 & 1 & 4 & 50 \\
\hline Total & & 13 & 31 & 7 & 44 & 70.45 \\
\hline
\end{tabular}

Results in Table (7) revealed that $4 \mathrm{Kr}$ treatment had the highest total number of polymorphic bands (29) with $69.05 \%$ polymorphism percentage, whereas the $2 \mathrm{Kr}$ treatment had 25 polymorphic bands with
$62.5 \%$ polymorphism percentage. Each treatment was compared individually with the control.

The HB12 primer gave the highest total number of polymorphic bands (14), whereas the UBC836 primer had the lowest one (4). 
Table 7. Effect of gamma irradiation treatments on polymorphism percentage via ISSR markers.

\begin{tabular}{|c|c|c|c|c|c|c|c|}
\hline \multirow{2}{*}{$\begin{array}{l}\text { Treatment } \\
\text { Primer } \\
\text { Code }\end{array}$} & \multicolumn{2}{|c|}{$2 \mathrm{Kr}$} & \multicolumn{4}{|c|}{$4 \mathrm{Kr}$} & \multirow{2}{*}{$\begin{array}{l}\text { Total BMB } \\
\text { Per primer }\end{array}$} \\
\hline & $\begin{array}{c}\text { No. } \\
\text { PMB }\end{array}$ & $\begin{array}{c}\text { No. } \\
\text { MMB }\end{array}$ & Total & $\begin{array}{c}\text { No. } \\
\text { PMB }\end{array}$ & $\begin{array}{c}\text { No. } \\
\text { MMB }\end{array}$ & Total & \\
\hline UBC 848 & 4 & 5 & 9 & 6 & 4 & 10 & 10 \\
\hline HB 12 & 7 & 3 & 10 & 7 & 3 & 10 & 14 \\
\hline $844 \mathrm{~A}$ & 6 & 2 & 8 & 7 & 2 & 9 & 13 \\
\hline $17889 \mathrm{~A}$ & 6 & 3 & 9 & 7 & 2 & 9 & 13 \\
\hline UBC 836 & 2 & 2 & 4 & 2 & 2 & 4 & 4 \\
\hline Total & 25 & 15 & 40 & 29 & 13 & 42 & \\
\hline Polymorphism \% & 62.5 & & & 69.05 & & & \\
\hline
\end{tabular}

$\mathrm{PMB}=$ Polymorphic bands, $\mathrm{MMB}=$ Monomorphic bands

Each treatment compared individually with the control

\section{RAPD analysis}

Nine random primers were used to differentiate among the irradiation treatments. All the primers were polymorphic (Fig. 3 and Tables 8 and 9).

The OPA-01 primer gave 13 different bands sized from 3769 to $400 \mathrm{bp}$. Twelve of which were polymorphic bands with $92.31 \%$ polymorphism percentage and one was monomorphic with size of $1200 \mathrm{bp}$. It was clear that molecular sizes of 433 and $400 \mathrm{bp}$ were presented only in one selection of $4 \mathrm{Kr}$ treatment as unique bands.
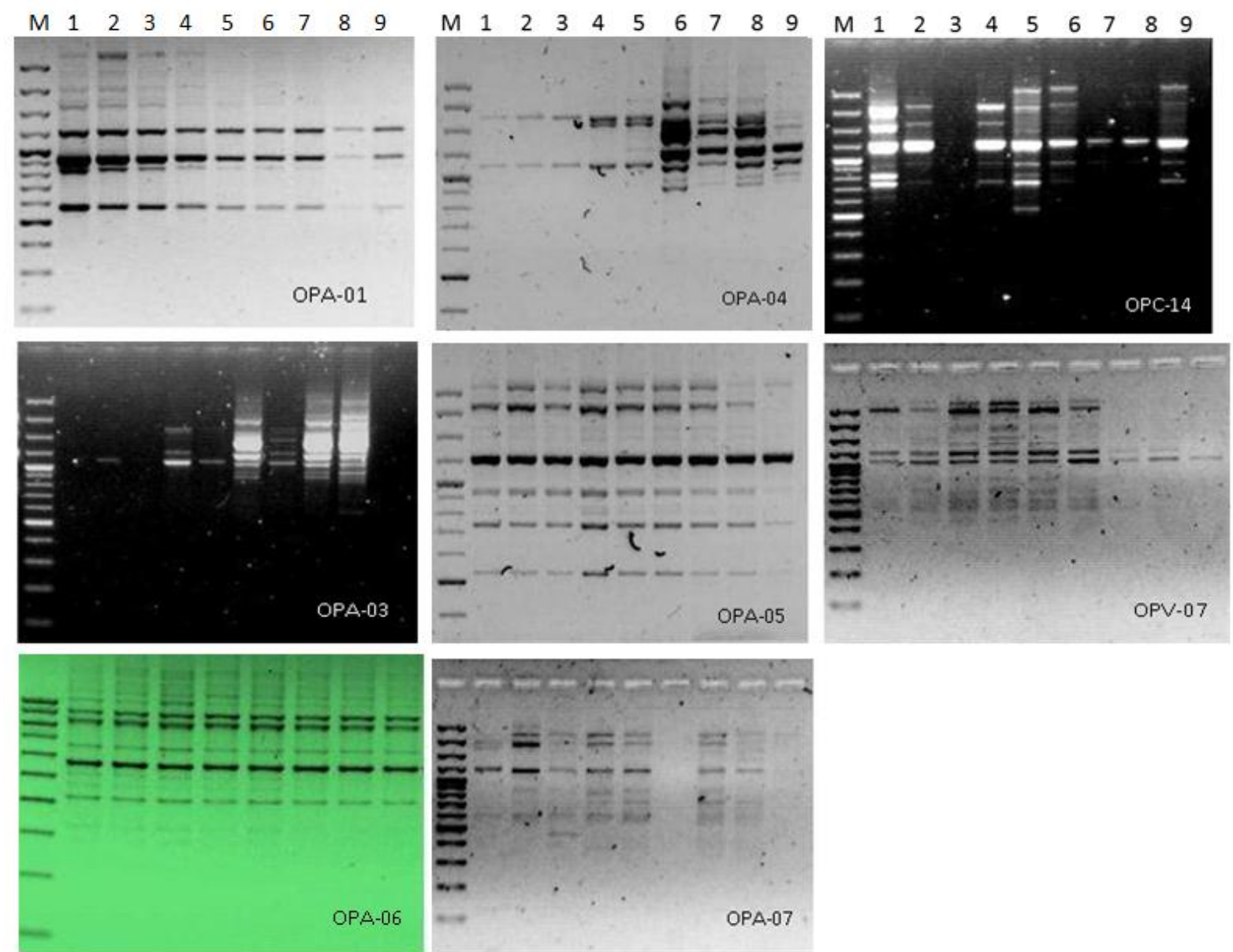

Fig. 3. RAPD-PCR analysis of genomic DNA polymorphism of Balady mandarin plants resulted from irradiated buds using different random primers with nine primers. (M:100bp DNA Ladder, 1: control, 2-5: 2 Kr, 6-9: $4 \mathrm{Kr}$ ).

The application of OPA-02 primer revealed the amplification of 11 bands with sizes ranged from 1401 to $426 \mathrm{bp}$, nine of them were polymorphic with $81.82 \%$ polymorphism percentage. The sizes of 1401 and $1092 \mathrm{bp}$ were monomorphic. Bands with sizes of 1000 and $700 \mathrm{bp}$ were found once in $2 \mathrm{Kr}$ selections, whereas the 500 and 426 bp sizes were presented only one time in one of $4 \mathrm{Kr}$ selections.

The OPA-03primer separated 19 amplified bands with sizes ranging from 9794 to $200 \mathrm{bp}$, out of them, 18 were polymorphic (94.74\%), and one was monomorphic (1000 bp) where it was present in all the 
treatment selections. The bands with sizes of 7222 , 4655,1470 and $700 \mathrm{bp}$ were found as unique bands in the $4 \mathrm{Kr}$ treatment selections, whereas the $200 \mathrm{bp}$ was found only in one selection of $2 \mathrm{Kr}$ treatment. The OPA-04 primer exhibited 10 different bands ranging from 3743 to $950 \mathrm{bp}$, nine of them were polymorphic (90\%), and one monomorphic (1097 bp). Moreover, it is clear from the data in Table (8) that bands with sizes of 2000, 1500, 1000 and 950 bp were present only in $4 \mathrm{Kr}$ treatment selections and absent from the control and $2 \mathrm{Kr}$ selections. The OPA-05 primer separated 16 different bands with sizes ranging from 3674 to 527 bp, twelve of them were polymorphic (75\%), of which one with size of $700 \mathrm{bp}$ was unique band where it was present only in one $2 \mathrm{Kr}$ selection. The four bands with sizes of 1200, 900, 737 and $527 \mathrm{bp}$ were monomorphic bands. The OPA-06 primer gave 15 different bands sized from 12999 to $668 \mathrm{bp}$, four of them $(3000,1000$, 932 and $800 \mathrm{bp}$ ) were monomorphic. The $2000 \mathrm{bp}$ size band was absent only from one of $2 \mathrm{Kr}$ selections, whereas the $700 \mathrm{bp}$ band was missing from one of the $4 \mathrm{Kr}$ treatment selections. The polymorphism percentage of this primer was $73.33 \%$ (Table 9).

Table 8. Amplified fragment obtained from the DNAs of Balady mandarin plants resulted from irradiated buds via RAPD -PCR.

\begin{tabular}{|c|c|c|c|c|c|c|c|c|c|c|}
\hline \multirow{2}{*}{$\begin{array}{l}\text { Primer } \\
\text { cod }\end{array}$} & \multirow{2}{*}{$\begin{array}{l}\text { Size } \\
\text { (bp) }\end{array}$} & \multirow[t]{2}{*}{ Control } & \multicolumn{4}{|c|}{$2 \mathrm{Kr}$} & \multicolumn{4}{|c|}{$4 \mathrm{Kr}$} \\
\hline & & & 1 & 2 & 3 & 4 & 1 & 2 & 3 & 4 \\
\hline \multirow[t]{13}{*}{ OPA-01 } & 3769 & 1 & 1 & 1 & 1 & 1 & 1 & 0 & 1 & 0 \\
\hline & 3000 & 0 & 0 & 0 & 1 & 0 & 0 & 1 & 1 & 0 \\
\hline & 2768 & 1 & 1 & 1 & 0 & 0 & 0 & 0 & 0 & 0 \\
\hline & 2000 & 1 & 1 & 1 & 1 & 0 & 0 & 0 & 0 & 0 \\
\hline & 1766 & 0 & 1 & 0 & 0 & 0 & 0 & 1 & 0 & 0 \\
\hline & 1667 & 1 & 1 & 1 & 1 & 1 & 1 & 0 & 0 & 0 \\
\hline & 1200 & 1 & 1 & 1 & 1 & 1 & 1 & 1 & 1 & 1 \\
\hline & 965 & 0 & 0 & 0 & 1 & 0 & 0 & 0 & 1 & 1 \\
\hline & 941 & 1 & 1 & 1 & 0 & 1 & 1 & 1 & 0 & 0 \\
\hline & 800 & 1 & 1 & 1 & 1 & 1 & 1 & 0 & 0 & 0 \\
\hline & 600 & 1 & 1 & 1 & 1 & 1 & 1 & 1 & 0 & 1 \\
\hline & 433 & 0 & 0 & 0 & 0 & 0 & 0 & 0 & 0 & 1 \\
\hline & 400 & 0 & 0 & 0 & 0 & 0 & 0 & 0 & 0 & 1 \\
\hline \multirow[t]{11}{*}{ OPA-02 } & 1401 & 1 & 1 & 1 & 1 & 1 & 1 & 1 & 1 & 1 \\
\hline & 1200 & 1 & 1 & 1 & 1 & 1 & 1 & 0 & 1 & 0 \\
\hline & 1092 & 1 & 1 & 1 & 1 & 1 & 1 & 1 & 1 & 1 \\
\hline & 1000 & 0 & 0 & 1 & 0 & 0 & 0 & 0 & 0 & 0 \\
\hline & 900 & 0 & 1 & 0 & 1 & 0 & 0 & 0 & 0 & 0 \\
\hline & 842 & 1 & 0 & 1 & 1 & 0 & 0 & 0 & 1 & 0 \\
\hline & 800 & 0 & 0 & 0 & 0 & 0 & 0 & 1 & 1 & 0 \\
\hline & 740 & 1 & 0 & 1 & 1 & 0 & 1 & 0 & 0 & 0 \\
\hline & 700 & 0 & 1 & 0 & 0 & 0 & 0 & 0 & 0 & 0 \\
\hline & 500 & 0 & 0 & 0 & 0 & 0 & 0 & 1 & 0 & 0 \\
\hline & 426 & 0 & 0 & 0 & 0 & 0 & 0 & 1 & 0 & 0 \\
\hline \multirow[t]{16}{*}{ OPA-03 } & 9794 & 0 & 0 & 0 & 0 & 0 & 0 & 0 & 1 & 1 \\
\hline & 7222 & 0 & 0 & 0 & 0 & 0 & 0 & 0 & 0 & 1 \\
\hline & 6638 & 0 & 0 & 0 & 0 & 0 & 0 & 0 & 1 & 1 \\
\hline & 5613 & 0 & 0 & 0 & 0 & 0 & 0 & 0 & 1 & 1 \\
\hline & 4655 & 0 & 0 & 0 & 0 & 0 & 0 & 0 & 0 & 1 \\
\hline & 3857 & 0 & 0 & 0 & 0 & 0 & 0 & 1 & 1 & 1 \\
\hline & 3000 & 0 & 0 & 0 & 0 & 0 & 0 & 1 & 1 & 1 \\
\hline & 2000 & 0 & 0 & 0 & 0 & 0 & 0 & 1 & 1 & 1 \\
\hline & 1824 & 0 & 0 & 0 & 1 & 0 & 1 & 1 & 1 & 1 \\
\hline & 1500 & 0 & 0 & 0 & 0 & 1 & 1 & 1 & 1 & 1 \\
\hline & 1470 & 0 & 0 & 0 & 0 & 0 & 0 & 1 & 0 & 0 \\
\hline & 1318 & 0 & 0 & 0 & 0 & 0 & 1 & 0 & 1 & 1 \\
\hline & 1200 & 0 & 0 & 0 & 1 & 0 & 1 & 1 & 1 & 1 \\
\hline & 1000 & 1 & 1 & 1 & 1 & 1 & 1 & 1 & 1 & 1 \\
\hline & 900 & 0 & 0 & 0 & 0 & 0 & 1 & 0 & 1 & 1 \\
\hline & 800 & 0 & 0 & 0 & 0 & 0 & 1 & 0 & 1 & 1 \\
\hline
\end{tabular}




\begin{tabular}{|c|c|c|c|c|c|c|c|c|c|c|}
\hline & 700 & 0 & 0 & 0 & 0 & 0 & 0 & 0 & 1 & 0 \\
\hline & 500 & 1 & 0 & 0 & 0 & 0 & 0 & 0 & 0 & 1 \\
\hline & 200 & 0 & 1 & 0 & 0 & 0 & 0 & 0 & 0 & 0 \\
\hline \multirow[t]{10}{*}{ OPA-04 } & 3743 & 0 & 0 & 0 & 0 & 0 & 0 & 0 & 0 & 1 \\
\hline & 2000 & 0 & 0 & 0 & $\overline{0}$ & 0 & 1 & 1 & 1 & $\overline{0}$ \\
\hline & 1838 & 0 & 1 & 0 & 0 & 0 & 0 & 0 & 0 & 1 \\
\hline & 1742 & 1 & 0 & 1 & 1 & 1 & 0 & 1 & 0 & 1 \\
\hline & 1609 & 0 & 0 & 0 & 1 & 1 & 1 & 1 & 1 & 1 \\
\hline & 1500 & 0 & 0 & 0 & 0 & 0 & 1 & 1 & 1 & 0 \\
\hline & 1226 & 0 & 0 & 0 & 0 & 1 & 1 & 1 & 1 & 1 \\
\hline & 1097 & 1 & 1 & 1 & 1 & 1 & 1 & 1 & 1 & 1 \\
\hline & 1000 & 0 & 0 & 0 & 0 & 0 & 1 & 0 & 1 & 1 \\
\hline & 950 & 0 & 0 & 0 & 0 & 0 & 1 & 1 & 1 & 0 \\
\hline \multirow[t]{16}{*}{ OPA-05 } & 3674 & 0 & 0 & 0 & 0 & 0 & 0 & 0 & 1 & 1 \\
\hline & 3000 & 1 & 1 & 1 & 1 & 1 & 1 & 1 & 0 & 0 \\
\hline & 2294 & 1 & 1 & 1 & 0 & 1 & 1 & 1 & 1 & 0 \\
\hline & 2091 & 0 & 0 & 0 & 1 & 0 & 0 & 0 & 0 & 1 \\
\hline & 1681 & 0 & 0 & 0 & 1 & 1 & 1 & 1 & 1 & 1 \\
\hline & 1569 & 1 & 0 & 1 & 0 & 0 & 0 & 0 & 0 & 0 \\
\hline & 1500 & 0 & 1 & 0 & 1 & 1 & 0 & 0 & 0 & 0 \\
\hline & 1200 & 1 & 1 & 1 & 1 & 1 & 1 & 1 & 1 & 1 \\
\hline & 1050 & 0 & 0 & 0 & 1 & 0 & 1 & 0 & 0 & 0 \\
\hline & 900 & 1 & 1 & 1 & 1 & 1 & 1 & 1 & 1 & 1 \\
\hline & 818 & 1 & 0 & 0 & 1 & 0 & 0 & 0 & 0 & 0 \\
\hline & 737 & 1 & 1 & 1 & 1 & 1 & 1 & 1 & 1 & 1 \\
\hline & 700 & 0 & 0 & 0 & 0 & 1 & 0 & 0 & 0 & 0 \\
\hline & 600 & 0 & 0 & 0 & 0 & 1 & 1 & 0 & 0 & 0 \\
\hline & 548 & 0 & 1 & 0 & 1 & 0 & 0 & 0 & 0 & 0 \\
\hline & 527 & 1 & 1 & 1 & 1 & 1 & 1 & 1 & 1 & 1 \\
\hline \multirow[t]{15}{*}{ OPA-06 } & 12999 & 0 & 1 & 1 & 1 & 1 & 1 & 0 & 0 & 0 \\
\hline & 10862 & 0 & 0 & 1 & 0 & 1 & 1 & 1 & 1 & 1 \\
\hline & 5683 & 1 & 1 & 1 & 0 & 0 & 1 & 1 & 1 & 0 \\
\hline & 3000 & 1 & 1 & 1 & 1 & 1 & 1 & 1 & 1 & 1 \\
\hline & 2000 & 1 & 1 & 0 & 1 & 1 & 1 & 1 & 1 & 1 \\
\hline & 1752 & 0 & 0 & 1 & 1 & 1 & 1 & 1 & 1 & 0 \\
\hline & 1500 & 1 & 1 & 1 & 1 & 0 & 0 & 0 & 0 & 1 \\
\hline & 1200 & 0 & 0 & 0 & $\overline{0}$ & 1 & 1 & 1 & 1 & 1 \\
\hline & 1000 & 1 & 1 & 1 & 1 & 1 & 1 & 1 & 1 & 1 \\
\hline & 932 & 1 & 1 & 1 & 1 & 1 & 1 & 1 & 1 & 1 \\
\hline & 900 & 1 & 1 & 1 & 0 & 1 & 1 & 1 & 0 & 0 \\
\hline & 481 & 0 & 0 & 0 & 1 & 1 & 1 & 0 & 0 & 0 \\
\hline & 800 & 1 & 1 & 1 & 1 & 1 & 1 & 1 & 1 & 1 \\
\hline & 700 & 1 & 1 & 1 & 1 & 1 & 0 & 1 & 1 & 1 \\
\hline & 668 & 1 & 0 & 1 & 0 & 0 & 0 & 0 & 1 & 0 \\
\hline \multirow[t]{12}{*}{ OPA-07 } & 5215 & 0 & 0 & 0 & 0 & 0 & 0 & 0 & 0 & 1 \\
\hline & 3000 & 0 & 1 & 1 & 1 & 1 & 0 & 1 & 1 & 0 \\
\hline & 2000 & 1 & 1 & 1 & 1 & 1 & 0 & 1 & 1 & 0 \\
\hline & 1732 & 1 & 0 & 0 & 0 & 0 & 0 & 0 & 0 & 0 \\
\hline & 1200 & 1 & 1 & 1 & 1 & 1 & 0 & 1 & 1 & 0 \\
\hline & 1000 & 0 & 1 & 0 & 0 & 1 & 0 & 0 & 0 & 0 \\
\hline & 900 & 0 & 0 & 0 & 1 & 0 & 0 & 1 & 0 & 1 \\
\hline & 800 & 0 & 0 & 0 & 1 & 1 & 1 & 0 & 1 & 1 \\
\hline & 700 & 1 & 0 & 1 & 0 & 0 & 0 & 1 & 0 & 0 \\
\hline & 668 & 0 & 1 & 0 & 1 & 1 & 0 & 0 & 0 & 0 \\
\hline & 600 & 0 & 0 & 0 & $\overline{0}$ & 0 & $\overline{0}$ & 0 & 1 & $\overline{0}$ \\
\hline & 500 & 0 & 0 & 1 & 0 & 0 & 0 & 0 & 0 & 1 \\
\hline
\end{tabular}




\begin{tabular}{|c|c|c|c|c|c|c|c|c|c|c|}
\hline & 458 & 0 & 0 & 0 & 1 & 0 & 0 & 1 & 0 & 0 \\
\hline \multirow[t]{16}{*}{ OPC-14 } & 5618 & 0 & 0 & 0 & 0 & 1 & 0 & 0 & 0 & 1 \\
\hline & 4786 & 0 & 1 & 1 & 1 & 0 & 0 & 0 & 0 & 1 \\
\hline & 4070 & 1 & 1 & 1 & 1 & 0 & 0 & 0 & 0 & 0 \\
\hline & 3542 & 0 & 0 & 0 & 1 & 1 & 1 & 0 & 0 & 1 \\
\hline & 3000 & 0 & 0 & 1 & 0 & 0 & 0 & 0 & 1 & 0 \\
\hline & 2344 & 1 & 1 & 1 & 1 & 1 & 1 & 1 & 0 & 1 \\
\hline & 2000 & 1 & 0 & 0 & 0 & 1 & 1 & 0 & 0 & 1 \\
\hline & 1691 & 0 & 1 & 1 & 1 & 1 & 0 & 1 & 0 & 0 \\
\hline & 1500 & 1 & 0 & 1 & 0 & 1 & 1 & 0 & 1 & 1 \\
\hline & 1200 & 1 & 1 & 1 & 1 & 1 & 1 & 1 & 1 & 1 \\
\hline & 1000 & 1 & 1 & 0 & 1 & 1 & 1 & 1 & 1 & 1 \\
\hline & 900 & 1 & 0 & 1 & 0 & 1 & 1 & 1 & 0 & 0 \\
\hline & 800 & 0 & 1 & 1 & 1 & 0 & 1 & 0 & 0 & 1 \\
\hline & 700 & 1 & 0 & 0 & 0 & 1 & 0 & 0 & 0 & 0 \\
\hline & 600 & 1 & 0 & 0 & 0 & 0 & 0 & 0 & 0 & 0 \\
\hline & 500 & 0 & 0 & 0 & 0 & 1 & 0 & 0 & 0 & 0 \\
\hline \multirow[t]{10}{*}{ OPV-07 } & 3962 & 0 & 0 & 1 & 1 & 1 & 1 & 0 & 0 & 0 \\
\hline & 3000 & 1 & 1 & 1 & 1 & 1 & 1 & 0 & 0 & 0 \\
\hline & 2000 & 0 & 0 & 1 & 1 & 1 & 0 & 0 & 0 & 0 \\
\hline & 1500 & 0 & 1 & 1 & 1 & 1 & 0 & 0 & 0 & 0 \\
\hline & 1342 & 1 & 0 & 1 & 1 & 1 & 1 & 1 & 0 & 0 \\
\hline & 1200 & 0 & 1 & 1 & 1 & 1 & 1 & 1 & 1 & 1 \\
\hline & 1000 & 1 & 1 & 0 & 1 & 0 & 0 & 0 & 0 & 0 \\
\hline & 900 & 0 & 1 & 0 & 1 & 1 & 0 & 0 & 1 & 0 \\
\hline & 800 & 0 & 0 & 1 & 1 & 1 & 1 & 0 & 1 & 0 \\
\hline & 700 & 0 & 1 & 1 & 1 & 1 & 1 & 1 & 0 & 0 \\
\hline
\end{tabular}

Results of OPA-07 primer exhibited the amplification of 13 bands with sizes ranged from 5215 to $458 \mathrm{bp}$; all of them were polymorphic with $100 \%$ polymorphism percentage. The bands with sizes of 5215 and $600 \mathrm{bp}$ were present only one time in $4 \mathrm{Kr}$ treatment. The 1732 bp size band was present only in the control and absent from the other treatment selections. The OPC-14 primer separated 16 bands with sizes ranged from 5618 to $500 \mathrm{bp}$. The band sized 1200 bp was monomorphic, whereas the other 15 bands were polymorphic with polymorphism percentage of $100 \%$. The band sized $600 \mathrm{bp}$ was found only in the control and absent from the 2 and $4 \mathrm{Kr}$ selections. While, the band with size of $500 \mathrm{bp}$ was present only in one of $2 \mathrm{Kr}$ selections.

Results of OPV-07 primer showed 10 different bands with sizes ranged from 3962 to $700 \mathrm{bp}$. All of them were polymorphic (100\%). The 1500 bp band was present only in the $2 \mathrm{Kr}$ selections and was missing from the control and $4 \mathrm{Kr}$ selections. The $1200 \mathrm{bp}$ band was missing in the control treatment and found in all other treatments selections.

Data presented in Table (9) showed that the nine used RAPD primers produced a total of 123 amplified bands, out of them 109 were polymorphic with $88.62 \%$ polymorphism percentage.

Table 9. Number and types of the amplified DNA bands as well as the total polymorphism percentage generated by nine RAPD primers in Balady mandarin buds irradiation.

\begin{tabular}{|c|c|c|c|c|c|c|}
\hline $\begin{array}{c}\text { Primer code } \\
\text { No. }\end{array}$ & Primer Sequence $5 \rightarrow 3^{-}$ & $\begin{array}{l}\text { No. } \\
\text { MMB }\end{array}$ & $\begin{array}{l}\text { No. } \\
\text { PMB }\end{array}$ & $\begin{array}{l}\text { Unique } \\
\text { bands }\end{array}$ & $\begin{array}{l}\text { Total } \\
\text { bands }\end{array}$ & Polymorphism \% \\
\hline OPA-01 & $5^{\prime}-$ CAGGCCCTTC -3' & 1 & 12 & 2 & 13 & 92.31 \\
\hline OPA-02 & $5^{\prime}$ - TGCCGAGCTG -3' & 2 & 9 & 4 & 11 & 81.82 \\
\hline OPA-03 & 5'- AGTCAGCCAC -3' & 1 & 18 & 5 & 19 & 94.74 \\
\hline OPA-04 & 5'- AATCGGGCTG -3' & 1 & 9 & 1 & 10 & 90.00 \\
\hline OPA-05 & 5'- AGGGGTCTTG -3' & 4 & 12 & 1 & 16 & 75.00 \\
\hline OPA-06 & $5^{\prime}$ - GGTCCCTGAC -3' & 4 & 11 & 0 & 15 & 73.33 \\
\hline OPA-07 & 5'- GAAACGGGTG 3' & 0 & 13 & 3 & 13 & 100.0 \\
\hline OPC-14 & $5^{\prime}$ - TGCGTGCTTG -3' & 1 & 15 & 2 & 16 & 93.75 \\
\hline OPV-07 & $5^{\prime}$ - GAAGCCAGCC 3' & 0 & 10 & 0 & 10 & 100.00 \\
\hline Total & & 14 & 109 & 18 & 123 & 88.62 \\
\hline
\end{tabular}

PMB = Polymorphic bands, $\mathrm{MMB}=$ Monomorphic bands 
The OPA-03 primer gave the highest total polymorphic bands, while OPA-04 and OPV-07 primers recorded the lowest ones.

Furthermore, the percentage of polymorphism produced by each primer differed from one primer to another, where the maximum value of polymorphism was $100 \%$ produced by OPA-07 and OPV-07. However, the lowest value was $73.33 \%$ for OPA-06.

From the polymorphic bands there were unique bands which considered valuable markers. The highest value of unique bands was scored with OPA03 primer.
Regarding the treatment effect, Table (10) revealed the comparison between each irradiation treatments individually with the control in the number of polymorphic bands, total number of polymorphic bands and polymorphism percentage, using the nine RADP primers. It was clear that the $4 \mathrm{Kr}$ treatment gave the highest total number of polymorphic bands (93), with $85.32 \%$ polymorphism percentage, whereas the $2 \mathrm{Kr}$ produced 72 polymorphic bands with $74.23 \%$ polymorphism percentage. From the above mentioned results, it was clear that $4 \mathrm{Kr}$ treatment achieved more genetic variation than the $2 \mathrm{Kr}$ in comparison with the control.

Table 10. Effect of gamma irradiation treatments on polymorphism percentage via RAPD markers.

\begin{tabular}{|c|c|c|c|c|c|c|c|}
\hline Treatment & & $2 \mathrm{Kr}$ & & & $4 \mathrm{Kr}$ & & Total \\
\hline $\begin{array}{l}\text { Primer } \\
\text { Code }\end{array}$ & $\begin{array}{c}\text { No. } \\
\text { PMB }\end{array}$ & $\begin{array}{c}\text { No. } \\
\text { MMB }\end{array}$ & Total & $\begin{array}{c}\text { No. } \\
\text { PMB }\end{array}$ & $\begin{array}{c}\text { No. } \\
\text { MMB }\end{array}$ & Total & $\begin{array}{c}\text { BMB } \\
\text { per } \\
\text { primer }\end{array}$ \\
\hline OPA-01 & 6 & 5 & 11 & 12 & 1 & 13 & 18 \\
\hline OPA-02 & 5 & 3 & 8 & 6 & 2 & 8 & 11 \\
\hline OPA-03 & 5 & 1 & 6 & 17 & 1 & 18 & 22 \\
\hline OPA-04 & 4 & 1 & 5 & 9 & 1 & 10 & 13 \\
\hline OPA-05 & 10 & 5 & 15 & 9 & 4 & 13 & 19 \\
\hline OPA-06 & 10 & 5 & 15 & 10 & 5 & 15 & 20 \\
\hline OPA-07 & 9 & 2 & 11 & 11 & 0 & 11 & 20 \\
\hline OPC-14 & 14 & 2 & 16 & 11 & 2 & 13 & 25 \\
\hline OPC-07 & 9 & 1 & 10 & 8 & 0 & 8 & 17 \\
\hline Total & 72 & 25 & 97 & 93 & 16 & 109 & \\
\hline Polymorphism \% & 74.23 & & & 85.32 & & & \\
\hline
\end{tabular}

PMB = Polymorphic bands, MMB = Monomorphic bands

Each treatment compared individually with the control

\section{Total protein analysis by SDS-PAGE}

The electrophoretic profiles of the control and four selections of each irradiation treatment are presented in Figure (4) and the banding pattern in Table (11). The analysis of total protein revealed 25 bands with different molecular weights. Among the bands, 23 showed high variability while, the other two bands were commonly detected in the studied selections.

Gamma irradiation treatments induced changes in the electrophoretic profiles. These changes include alteration in band intensities, appearance of new bands and disappearance of others. The most visible changes in SDS-PAGE patterns were the appearance of new bands with molecular weight of 264, 196 and $139 \mathrm{KD}_{\mathrm{a}}$ in some selections of $4 \mathrm{Kr}$ treatment, and bands of 87 , $86,82,51,45,30$ and $9 \mathrm{KD}_{\mathrm{a}}$ in selections of 2 and 4 $\mathrm{Kr}$. The protein bands with molecular weight of 166 and $164 \mathrm{KDa}$ were disappeared after irradiation treatment from all 2 and $4 \mathrm{Kr}$ selections except one selection in $2 \mathrm{Kr}$ treatment. The protein bands with molecular weight of 172, 136, 123, 116, 97, 76, 66, 55 and $39 \mathrm{KD}_{\mathrm{a}}$ were appeared in the control and disappeared from some irradiated selections. An over accumulation was also observed for protein bands with a molecular weight of 136, 123, 82, 45, 20 and $11 \mathrm{KD}_{\mathrm{a}}$.
The changes in protein banding patterns have been attributed to the occurrence of either gene mutation or induction of cytological aberrations. The absence of some bands might be due to the disruption of their corresponding genes.

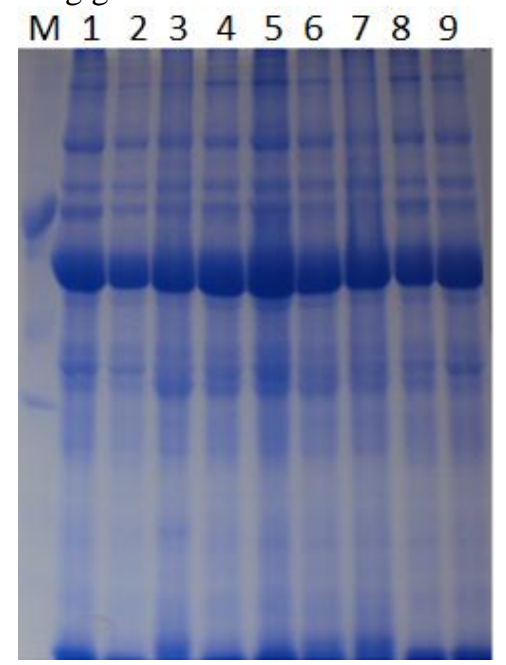

Fig. 4. SDS-Polyacrylamide gel electrophoresis showing protein bands patterns of Balady mandarin. M: marker (High molecular weight Sigma), Lane 1: control, Lane 2-5: 2Kr, Lane 6-10: $4 \mathrm{Kr}$. 
Table 11. SDS-PAGE banding patterns of total protein in plants induced from irradiation (Buds) treatments.

\begin{tabular}{|c|c|c|c|c|c|c|c|c|c|c|}
\hline $\begin{array}{c}\text { Band } \\
\text { No. }\end{array}$ & $\begin{array}{l}\text { M.wt. } \\
\text { (KDa) }\end{array}$ & 1 & 2 & 3 & 4 & 5 & 6 & 7 & 8 & 9 \\
\hline 1 & 273 & ++ & ++ & ++ & ++ & ++ & ++ & ++ & ++ & ++ \\
\hline 2 & 264 & - & - & - & - & - & - & - & + & + \\
\hline 3 & 223 & +++ & +++ & +++ & +++ & +++ & +++ & +++ & +++ & +++ \\
\hline 4 & 196 & - & - & - & - & - & - & - & ++ & ++ \\
\hline 5 & 172 & ++ & - & ++ & ++ & ++ & ++ & - & ++ & ++ \\
\hline 6 & 166 & ++ & - & - & - & ++ & - & - & - & - \\
\hline 7 & 164 & ++ & - & - & - & ++ & - & - & - & - \\
\hline 8 & 139 & - & - & - & - & - & - & - & +++ & +++ \\
\hline 9 & 136 & ++ & ++ & ++ & ++ & ++ & ++ & - & +++ & +++ \\
\hline 10 & 123 & ++ & ++ & - & +++ & - & +++ & - & +++ & +++ \\
\hline 11 & 116 & +++ & - & ++ & - & +++ & +++ & - & - & - \\
\hline 12 & 97 & ++ & - & ++ & - & ++ & ++ & ++ & - & - \\
\hline 13 & 87 & - & ++ & - & - & - & - & - & ++ & ++ \\
\hline 14 & 86 & - & ++ & - & + & - & - & + & + & - \\
\hline 15 & 82 & - & - & - & ++ & +++ & ++ & - & - & - \\
\hline 16 & 76 & + & - & - & + & - & + & + & + & + \\
\hline 17 & 66 & + & + & - & ++ & - & - & - & - & - \\
\hline 18 & 55 & + & + & + & + & - & - & - & + & ++ \\
\hline 19 & 51 & - & - & - & - & + & - & ++ & - & ++ \\
\hline 20 & 45 & - & - & + & + & ++ & ++ & - & ++ & +++ \\
\hline 21 & 39 & + & - & + & - & + & - & + & + & - \\
\hline 22 & 30 & - & - & - & ++ & - & - & - & + & + \\
\hline 23 & 20 & ++ & - & ++++ & +++ & ++++ & ++++ & - & +++ & +++ \\
\hline 24 & 11 & + & - & ++ & - & + & + & + & + & ++ \\
\hline 25 & 9 & - & - & - & - & ++ & - & ++ & - & - \\
\hline
\end{tabular}

++++ very strong +++ strong ++ intermediate + weak - absent
1: control
2-5: $2 \mathrm{Kr}$ treatment selections
6-9: $4 \mathrm{Kr}$ treatment selections

\section{Discussion}

This study includes the using of gamma rays at different doses to induce genetic variations in Balady mandarin using buds as irradiated material. The obtained data (Fig. 1) revealed that bud sprouting percentage decreased by increasing the dose of gamma rays. The $\mathrm{LD}_{50}$ was obtained at $2.1 \mathrm{Kr}$. From this results it is clear that the buds were sensitive and this in agreement with the result of Spiegel-Roy and Padova (1973), who reported that the $\mathrm{LD}_{50}$ for Citrus sinensis seeds was between 8 and $10 \mathrm{Kr}$, whereas it was below $5 \mathrm{Kr}$ for buds and the $7.5 \mathrm{Kr}$ was almost lethal to the buds. Gulsen et al. (2007) reported that the $\mathrm{LD}_{50}$ of 'Kutdiken' lemon buds was around $5 \mathrm{Kr}$. Whereas, Ling et al. (2008) found the $\mathrm{LD}_{50}$ of Citrus sinensis seeds was achieved at $27 \mathrm{~Gy}$. From the previous result we can conclude that the buds are more sensitive to irradiation than seeds, this may be due to the lower moisture content and the presence of coats in the seeds. The morphological characters also affected by gamma irradiation (Table 3 and 4). It is clear that there were significant differences among treatments. The control had the highest values of shoot length, total leaf number/plant, area/leaf and total leaf area/plant in comparison with the irradiation treatments (Table 3). Stomatal parameters also differed significantly among treatments (Table 4). All the previous variations could be explained as a reflection of the genetic variations, that induced by radiation. These genetic variations were confirmed in our study through using the molecular and biochemical markers (ISSR, RAPD and protein gel electrophoresis) as screening techniques. Genetic variations among plants of Balady mandarin which regenerated from gamma irradiated buds was evaluated using ISSR and RAPD markers to detect the induced genetic variations among treatments. ISSR markers produced 44 amplified bands out of which 31 were polymorphic (Tables 5, 6). The RAPD markers generated 123 amplified bands out of which 109 were polymorphic (Tables 8, 9). RAPD fingerprinting detected more polymorphic bands $(88.62$ polymorphism percentage) than ISSR fingerprinting $(70.45 \%)$. Regarding the gamma ray treatment efficiency on inducing genetic variations, both ISSR and RAPD markers proved that $4 \mathrm{Kr}$ dose was more effective in inducing genetic variations than $2 \mathrm{Kr}$ compared to the control. The $4 \mathrm{Kr}$ treatment produced 69.05 and 85.32 polymorphism percentage by using ISSR and RAPD, respectively, whereas the $2 \mathrm{Kr}$ generated 62.5 and 74.23 polymorphism percentage (Tables 7 and 10). The previous results clear that both marker systems were effective in determining polymorphism and they were useful tools for diversity 
studies in Balady mandarin. Many researchers proved the usefulness and efficiency of ISSR and RAPD techniques in detecting genetic variation in different species and varieties (Bastianel et al., 1998; Reddy et al., 2002; Abkenar and Isshiki, 2003; Capparelli et al., 2004; Bosco et al., 2007; Baig et al., 2009; Biswas et al., 2010; Marak and Lasckar, 2010). Total protein electrophoresis was used as a biochemical marker to evaluate the changes in protein electrophoretic profiles in leaves of the irradiated plants. Changes include alteration in band intensities, appearance of new bands and disappearance of other bands were found (Table 11 and Fig. 4). These changes could be attributed to the occurrence of either gene mutation or induction of cytological aberrations, whereas the absence of some bands might be due to the disruption of their corresponding genes. Under stress conditions like irradiation, several stress proteins are synthesized and accumulated in plant tissues, as defenses mechanisms (Humera, 2006). This defense brought about by alteration in pattern of gene expression (Corthals et al., 2000) leading to modulation of certain metabolic and defensive pathways (Zolla et al., 2003). Moreover, Ling et al., (2008) reported that owing to gene expression altered under gamma stress, qualitative and quantitative changes in total soluble protein content was obvious.

In conclusion, the molecular markers (ISSR and RAPD) as well as biochemical markers (total protein) are a fast and simple techniques, can detect enough polymorphism to differentiate between irradiated Balady mandarin plants. These markers indicated the presence of an extensive genetic polymorphism among the studied treatment selections.

\section{References}

Abkenar, A.A. and S. Isshiki. 2003. Molecular characterization and genetic diversity among Japanese acid citrus (Citrus spp.) based on RAPD markers. J. Hort. Sci. Biotec. 78 (1): 108-112.

Baig, M.M.R., S. Grewal and S. Dhillon. 2009. Molecular characterization and genetic diversity analysis of citrus cultivars by RAPD markers. Turk. J. Agric., 33: 375-384.

Bastianel, M., S.F. Schwarz, H.D. Coletta Filho, L.L. Lin, M.A. Machado and O.C. Koller. 1998. Identification of zygotic and nucellar tangerine seedlings (Citrus spp.) using RAPD. Genet. Mol. Biol. 21 (1): 123-127.

Bhattacharya, S., T.K. Bandopadhyay, P.D. Ghosh. 2010. Somatic embryogenesis in Cymbopogon pendulus and evaluation of clonal fidelity of regenerants using ISSR marker. Scientia Horticulturae 123: 505-513.

Biswas, M.K., X.U. Qiang and X.X. Deng. 2010. Utility of RAPD, ISSR, IRAP and REMAP markers for the genetic analysis of Citrus spp. Scientia Horticulturae, 124 (2): 254-261.
Bosco, S.F., M. Siragusa, L. Abbate, S. Lucretti and N. Tusa. 2007. Production and characterization of new triploid seedless progenies for mandarin improvement. Scientia Horticulturae 114: 258-262.

Cameron, J. W. and H.B. Frost. 1968. Genetics, breeding and nucellar embryony. In: W. Reuther, L. D. Batchelor and H. J. Webber (eds.) The Citrus Industry. Vol. II University of California Press, Berkeley, Cliff. pp: 325-370.

Capparelli, R., M. Viscardi, M.G. Amoroso, G. Blaiotta and M. Bianco. 2004. Inter-simple sequence repeat markers and flow cytometry for the characterization of closely related Citrus limon germplasms. Biotechnology Letters 26:12951299.

Chandrika, M. and V.R. Rai. 2009. Genetic fidelity in micropropagated plantlets of Ochreinauclea missionis an endemic, threatened and medicinal tree using ISSR markers. African Journal of Biotechnology 8: 2933-2938

Chen, S., F. Gao, and J. Zhou. 1991. Studies on the seedless character of Citrus induced by irradiation. Mutation Breeding Newsletter 37: 8-9.

Cheng, M.L., L. Tao, C.M.L. Yuangang and L.Y.G. Pauci. 1997. Seed breeding and pollen pre-selection of physical mutagenic shatian shaddock. J. South China Agri. Univ. 18 (2): 1722.

Cipriani, G., D.R. Bella and R. Testolin. 1996. Screening RAPD primers for molecular taxonomy and cultivar fingerprinting in the genus Actinidia. Euphytica 90: 169-174.

Corthals, G., S. Gygi, R. Aebersold and S.D. Patterson. 2000. Identification of proteins by mass spectrometry. Proteome Res., 2 (1): 286-290.

Doyle, J.J. and J.L. Doyle. 1990. A rapid total DNA preparartion procedure from fresh plant tissue. Focus 12: 13-15.

Duncan, D.B. 1955. Multiple ranges and multiple tests. Biometrics, 11: 1-24.

Espino, R.C., A.B. Zamora and R.B. Pimentel. 1986. Mutation breeding on selected Philippines fruit crops. In: Nuclear techniques and in vitro culture for plant improvement. Proc. Symposium, Vienna, Austria: 429-433.

Fang, D.Q. and M.L. Roose.1997. Identification of closely related citrus cultivars with inter-simple sequence repeat markers. Theor Appl Genet. 95:408-417.

Fang, D.Q., C.T. Federici, and M.L. Roose .1997. Development of molecular markers linked to a gene controlling fruit acidity in citrus. Genome 40: 841-849.

Federici, C.T., D.Q. Fang, R.W. Scora and M.L. Roose. 1998. Phylogenetic relationships within the genus Citrus (Rutaceae) and related genera as revealed by RFLP and RAPD analysis. Theor Appl Genet 94:812-822. 
Froneman, I.J., H.J. Breedt, P.J.J. Koekernor. 1996. Promising seedless citrus selection from the ITSC mutant breeding programmes. Bulletin Instituut vir Tropiese en Subtrpiese Gewasse. 292: 12-16.

Gulsen, O., M.L. Roose. 2001a. Lemons: diversity and relationships with selected Citrus genotypes as measured with nuclear genome markers. J Amer Soc Hort Sci 126:309-327.

Gulsen, O., M.L. Roose. 2001b. Chloroplast and nuclear genome analysis of the parentage of lemons. J Amer Soc Hort Sci 126:210-215.

Gulsen, O., A. Uzun, H. Pala, E. Canihos and G. Kafa. 2007. Development of seedless and mal secco tolerant mutant lemons through budwood irriadiation. Scientia Horticulturae, 12 (40): 184190.

Gulsen, O., A. Uzun, I., Canan, U., Seday and E. Canihos. 2010. A new citrus linkage map based on SRAP, SSR, ISSR, POGP, RGA and RAPD markers. Euphytica 173: 265-277.

Hearn, C.J. 1984. Development of seedless orange and grapefruit cultivars through seed irradiation. J. Amer. Soc. Hort. Sci. 109: 270-273.

Hearn, C.J. 1986. Development of seedless grapefruit cultivars through budwood irradiation. Journal American Society Horticulture Science 111: 304-306.

Humera, A. 2006. Biochemical and molecular markers of somaclonal variants and induced mutants of popato (Solanum tuberosum L.). Thesis (Ph.D.). University of the Punjab Lahore, Pakistan.

Hvarleva, T., T. Kapari-Isaia, I. Papayiannis, A. Atanassov, A. Hadjinicoli and A. Kyriakou. 2008. Characterization of Citrus Cultivars and Clones in Cyprus through Microsatellite and RAPD Analysis. Biotechnology \& Biotechnolological Equipment. 22: 787-794.

Krajnáková, J., S. Sutela, T. Aronen, D, Gömöry, A.., Vianello, and H. Häggman. 2011. Long-term cryopreservation of Greek fir embryogenic cell lines: Recovery, maturation and genetic fidelity. Cryobiology 63: 17-25.

Kukimura, H., F. Ikeda, H. Fujita and T. Maeta. 1976. Brief description of mutation in vegetatively propagated and tree crops. In Proceedings of the Gamma Field Symposium, Japan. pp. 79-82.

Ladizinsky G., and T. Hymowitz. 1979. Seed protein electrophoresis in taxonomic and evolutionary studies, Theor. Appl. Genet, 54: 145151.

Laemmli, V. 1970. Cleavage of structural proteins during assembly of the head of bacteriophage T4. Nature, 227:680.

Ling, A.P.K., J.Y. Chia, S. Hussein and A.R. Harun. 2008. Physiological responses of Citrus sinensis to gamma irradiation. World Applied Sciences Journal, 5 (1): 12-19.
Majd, F., E. Jahangirzadeh, S. Vedadi, M. Naseri and J. Rastegari. 2009. Mutation induction for improving of tangerine in Iran. IAEA-TEC DOC. 1615: 41-46.

Maluszynski, M., B.S. Ahloowalia and B. Sigurbjörnsson. 1995. Application of in vivo and in vitro mutation techniques for crop improvement. Euphytica, 85: 303-315.

Marak, C.K. and M.A. Lasckar. 2010. Analysis of phenetic relationship between Citrus indica Tanaka and a few commercially important citrus species by ISSR markers. Scientia Horticulturae 124 (3): 345-348.

Micke, A., M. Maluszynski, and B. Donini. 1985. Plant cultivars derived from mutation induction or the use of induced mutants in crop breeding. Mutation Breeding Reviews 3: 1-92.

Nicolosi, E., Z.N. Deng, A. Gentile, S. La Malfa, G. Continella, and E. Tribulato. 2000. Citrus phylogeny and genetic origin of important species as investigated by molecular markers. Theoretical and Applied Genetics, 100: 1155-1166.

Predieri, S. 2001. Mutaion induction and tissue culture in improving fruits. Plant Cell, Tissue and Organ Culture, 64: 185-210.

Reddy, M.P., M. Sarla and E.A. Siddiq. 2002. Inter simple sequence repeat (ISSR) polymorphism and its application in plant breeding. Euphytica 128: 917.

Shaaban, E.A., S. KH. Abd-EL-Aal, N.S. Zaied and A.A. Rizkalla. 2006. Assessment of Genetic Variability on Some Orange Accessions Using RAPD-DNA Markers. Research Journal of Agriculture and Biological Sciences, 2: 564-570.

Shahsavar, A.R., K. Izadpanah, E. Tafazoli, B.E. Sayed. 2007. Characterization of citrus germplasm including unknown variants by intersimple sequence repeat (ISSR) markers. Sci Hortic.112:310-314.

Snedecor, G.W. and W.G. Cochran. 1980. Statistical Methods. $7^{\text {th }}$ ed. The Iowa State Univ. Press, Ames.

Spiegel-Roy, P. 1990. Economic and agricultural impact of mutation breeding in fruit trees. Mutation Breeding Review 5: 1-26.

Spiegel-Roy, P. and R. Padova. 1973. Radiosensitivity of Shamouti orange (Citrus sinensis) seeds and buds. Rad. Bot. 13 (2): 105110.

Sugawara, K., T. Wakizuka, A. Oowada, T. Morigushi and M. Omura. 2002. Histogenic identification by RAPD analysis of leaves and fruit of newly synthesized chimeric citrus. J. Amer. Soc. Hort. Sci., 127: 104-107.

Sutarto, I., D. Agisimanto and A. Supriyanto. 2009. Development of promising seedless citrus mutants through gamma irradiation. In: Q. Y. Shu (ed.), Induced Plant Mutations in the Genomics Era. FAO, Rome. 306-308. 
Uzun, A., O. Gulsen, T. Yesiloglu, Y. Aka-Kacar, O. Tuzcu. 2010. Distinguishing grapefruit and pummel accessions using ISSR markers. Czech J Genet Plant Breed. 46:170-177.

William, J.G.K., A.R. Kubelik, K.J. Livak, J.A. Rafalski and S.V. Tingey. 1990. DNA polymorphism amplified by arbitrary primers are useful as genetic markers. Nucleic Acids Research. 18: 6531- 6535.

Wu, S., J. Liang, Z. Lin, X.Tang and S. Zeng. 1986. Using gamma rays to induce mutations for seedlessness in Citrus. Mutation Breeding Newsletter 27: 14-17.

Xiao, J.P., L.G. Chen, M. Xie, H.L. Liu and W.Q. Ye. 2009. Identification of AFLP fragments linked to seedlessness in Ponkan mandarin (Citrus reticulata Blanco) and conversion to SCAR markers. Scientia Horticulturae 121(4): 505-510.

Xu, L., U. Najeeb. M.S. Naeem, G.L. Wan, Z.L. Jin, F..Khan, and W.J. Zhou. 2012. In vitro mutagenesis and genetic improvement. In Technological Innovations in Major World Oil Crops, edited by Gupta, S.K. New York: SpringerVerlag. pp. 151-173.

Zolla, L., A.M. Timperio, W. Walcher and C.G. Huber. 2003. Proteomics of light harvesting proteins in different plant species. Plant Physiol., 131 (2): 198-214. 